\title{
ANALYSIS OF SOCIO-ECONOMIC CONDITIONS OF SEAWEED FARMERS IN NEMBERALA VILLAGE, WEST ROTE DISTRICT, INDONESIA
}

\author{
Sitompul Fanny Kristin Tantyah*, Magister Student \\ Faculty of Human Resource Development, University of Airlangga, Surabaya, Indonesia \\ Matasik Delfania \\ Trisakti Sustainability Center, Trisakti University, Jakarta, Indonesia \\ *E-mail: fannykts@gmail.com
}

\begin{abstract}
Seaweed was firstly cultivated in Nemberala Village in 1998 by Ibrahim Agustinus Meda who then ran as the regent of Kupang Regency. Since then, seaweed farmed has become a favourite job in Nemberala. This study aims to describe the socio-economic condition of seaweed farmers in Nemberala village. This study was conducted in Nemberala Village, West Rote District, East Nusa Tenggara by using a qualitative approach. Its result shows that the socio-economic status of seaweed farmer in Nemberala village is in the middle class. Seaweed farmer in Nemberala village has improved the level of education and community well-being as a result of the high income.
\end{abstract}

\section{KEY WORDS}

Social status, seaweed, seaweed farmer, education, occupational status, income.

Indonesia has the fourth-longest coastline in the world, which is around 95,181 KM spread by large and small islands. This coastline has the potential for the development of marine aquaculture. The potential for marine cultivation in Rote Ndao Regency is 112,210 $\mathrm{Ha}$. One of the economic development activities promoted by the government for the marine potential is seaweed cultivation. This research was conducted in Rote Ndao District because it is one of the districts that have a seaweed cultivation program and has a vast sea area of $112,210 \mathrm{Ha}$, and is well known overseas as a place for marine tourism destinations that has the potential to be developed.

Rote Ndao Regency is located in westernmost Indonesia which is borders directly with the Australian Continent. This regency is classified as an underdeveloped area in Indonesia (listed in the Presidential Regulation Number 131 of 2015 about Determination of Disadvantaged Regions Year 2015-2019). One area known as the seaweed cultivation area in Rote Ndao Regency is Nemberla Village. This program is expected to stimulate regional economic growth due to the increase in local people's income. Since 1998, the community in Nemberala village started to work as a seaweed farmer. Ibrahim Agustinus Meda carried a bucket, rope, seaweed seeds, waring net (used for drying seaweed), as well as involving the community to participate in cultivating the seaweed. At first, it was difficult to convince community to start working as seaweed farmer, because that was the new thing for community in Rote. Prior to seaweed, the community's jobs were Palmyra taper, mat weaver with pandan leaves, and copra seller with excessively low income compared to selling seaweed. Until now seaweed has remained as the highest income job compared to other jobs and has become a popular job in the village of Nemberala.According to Central Bureau of Statistics (BPS) data in 2008, income is classified into 4 groups, namely: very high income group (> Rp3,500,000 per month), high income group (Rp2,500,000 - Rp3,500,000 per month), middle income group (Rp1,500,000 - Rp 2,500,000 per month), and low income group (<Rp1,500,000 per month).

There are three indicators which can describe the socio-economic condition of seaweed farmer which can also be used to measured class social, namely education, occupational status, and income (Nichol, Brown, dan Haynes, 2011). Education plays an 
important role in determining person status in the society. Beside that, work is a very important part of our everyday lives, many individuals spend one-half or more of their waking hours in an occupational/work place. Moreover, the socioeconomic status we enjoy, and the accompanying quality of life, depends largely on our occupation. Therefore, work also influences our ability to earn income. Additionally, low income have been shown to be strong predictors of a range of physical and mental health problems. This problem may be due to environmental conditions in their househool or workplace. While, community with high income can easily fulfill the family needs, they can even buy luxury goods which also influences their social status in society. According to Central Bureau of Statistics (BPS) data in 2008, income is classified into 4 groups, namely: very high income group ( $>$ Rp3,500,000 per month), high income group (Rp2,500,000 - Rp3,500,000 per month), middle income group (Rp1,500,000 - Rp 2,500,000 per month), and low income group (< Rp1,500,000 per month). This study aims to analyse the socioeconomic condition and status of seaweed farmer in Nemberala Village.

\section{METHODS OF RESEARCH}

The method used in this research is a study case from the seaweed farmers in Nemberala Village in 2019. Nemberala village is located in Rote Barat Sub-district, Rote Ndao Regency. This study is carried out by qualitative research method which aims to reveal the real condition in a holistic contextual (comprehensive and contextual) through collecting data from respondents. Data collection includes primary and secondary data. Primary data has done by interviewing the key person and observation the life of the seaweed farmers directly. The determination of respondents in this study uses the snow-ball method until informasi yang dibutuhkan dari informan lengkap dan jenuh. Interviews and observation conducted with local governments - village head, dan sub-district head, seaweed middleman/traders, and seaweed farmers. Secondary data was obtained from the village office, statistics central agency, and previous research reports. Data analysis techniques are data reduction, data verification, and data presentation.

\section{RESULTS AND DISCUSSION}

Socio-economic conditions are conditions or positions that are regulated in a particular social context, as is the case with ownership relating to status, for example, income, employment and education (Soekanto, 2001). There are three indicators which can describe the socio-economic condition of seaweed farmer which can also be used to measured class social, namely education, occupational status, and income (Nichol, Brown, dan Haynes, 2011). The following is a description of the indicators of socioeconomic of seaweed farmers in Nemberala Village based on research results:

Education is one of the factors that influence socio-economic status and condition. Besides, education can help people to prepare themselves in the future. As stated by Sedarmayanti (2003), that through the education, someone is prepared to have the provision to be ready to know, understand and develop the methods of critical thinking system to solve problems which will be faced in the future. It can be concluded that education is very helpful for someone to live their life, including their social and economic life. The following is an overview of community education in Desa Nemberala in 2019:

Table 1 - Total Population of Nemberala Village based on Education of 2019

\begin{tabular}{|c|c|c|c|}
\hline \multirow{2}{*}{ Education Level } & Male & Total Population & \multirow{2}{*}{ Number } \\
\cline { 2 - 4 } & 93 & 103 & 196 \\
\hline Not attending school & 167 & 155 & 322 \\
\hline Elementary & 89 & 95 & 244 \\
\hline Junior High & 112 & 143 & 255 \\
\hline Senior High & 102 & 103 & 205 \\
\hline University & & \\
\hline
\end{tabular}

Source: Data was taken from each Neighbourhood Head (Kepala Rukun Tetangga) of March 2019. 
The education level of the majority of the community in Nemberala Village is Elementary School graduate. However, the awareness about the importance of education is increasing from generation to generation, as seen from the considerable percentage of residents with diploma and bachelor's degree, which is 17\% (205 people) in Nemberala Village. Generally, the communities who work as seaweed farmers still have low education, which is elementary school graduate. This was because the seaweed farmers are generation $\mathrm{X}$ who were previously difficult to obtain an education.

The improving of parent's awareness about the importance of education is one of the factors that contributed to improving the quality of education in Nemberala Village. Moreover, nowadays the education facility is accessible for the community. Moreover, since 1998 seaweed also took a big part to increase community education, because the income of community who is working as a seaweed farmer was rising rapidly. This factor indirectly impacts the community capacity in financing children education up to the level of higher education. Before working as a seaweed farmer, the number of community who were able to give proper education to their children was very limited. In addition to paying for school fees, the community also needs to prepare transportation costs, study materials, and allowances for their children. Currently, the children of seaweed farmers have started to pursue higher education to university level.

Job is another factor that becomes a benchmark to describe the socio-economic conditions of people in society. About $45 \%$ of the total population in Nemberala Village works as seaweed farmers, and the rest work as civil servants, private sector employees, etc. Below is a description of population in Nemberala village based on occupation:

Table 2 - Total Population of Nemberala Village based on Occupation of 2019

\begin{tabular}{|c|c|c|}
\hline No & Type of Occupation & Number (People) \\
\hline 1 & Civil servant & 75 \\
\hline 2 & Honorary employee & 27 \\
\hline 3 & Private sector employee & 209 \\
\hline 4 & Seaweed farmer & 317 \\
\hline \multicolumn{2}{|c|}{ Total } & 628 \\
\hline
\end{tabular}

Source: Data was taken from each Neighbourhood Head (Kepala Rukun Tetangga) of March 2019.

Apart from the above work, there are also several other jobs that have not been recorded by the local government, such as entrepreneurs (kiosk owners) and weavers. Today, most people choose to work as seaweed farmers, leaving their previous jobs because this work is more flexible on time, compared to other jobs. In addition, this work is also very easy and does not require special skills, even more economically profitable because people's income is higher, compared to other jobs.

The type of seaweed planted by the communities in Nemberala Villages is the green (SP) and brown seaweed types. The selling price of green seaweed from the collectors to farmers is around Rp18,000-Rp27,000/kg, while for the brown seaweed is priced at Rp8,000$\mathrm{Rp} 10,000 / \mathrm{kg}$. The price of seaweed was not only determined based on the seaweed quality, but also predominantly influenced by the buying price of companies in Surabaya. The seaweed farmers were unable to initiate negotiations on the seaweed selling price, thus those who preferred not to sell their seaweed produce could be stored.

The average of seaweed farmers has an agricultural land stretching up to 30 depak/line, whereas the required capital for seaweed farming if the farmers have a 30 depak area of seaweed farmland ( 1 depak $=1.5$ meter) are $10 \mathrm{~kg}$ nylon lines, 60 page of pig wood and 30 lines seedling seaweed. It costs around Rp8,500,000 for 30 depak/line seaweed farming. The working time of the seaweed farmers started from 14.00 Indonesian Central Time (WITA/Waktu Indonesia Tengah) up to $18.00 \mathrm{WITA}$, so that in the morning the people still have time to do other work, such as tapping Palmyra fruit, collecting copra, livestock farming, and weaving mats or making roofs from coconut leaves.

According to ISCO-08 (International Standard Classification of Occupation) in 2018, occupation is divided into 10 major groups, namely manager, professional, technicians and 
associate professionals, clerical support workers, services and sales workers, skilled agricultural, forestry and fishery workers, craft and related trades workers, plant and machine operators, and assemblers, elementary occupations, and armed forces occupation. Based on that, seaweed farmer is the part of major group six which is skilled agricultural, forestry and fishery workers. Competent performance in seaweed farmer requires skill at the second ISCO skill level. Some of tasks which performed by seaweed farmer include: nursery, planting, and harvesting. The seaweed cultivation was performed traditionally by the community, by binding the seaweed onto a nylon line tied to a peg wood.

Furthermore, based on the classification of employment status issued by BPS in 2001, from 7 occupational categories, seaweed farmers were categorized as self-employed workers In this case, seaweed farmer has to set the working time, overcome the challenges and bear the risks of work by their selves, and directly sell their produce to seaweed collectors individually. Some of the challenges that have been faced by seaweed farmer in Nemberala village are there were no excellent seedlings resistant to pest and water pollution, the distance of seaweed farmland is quite far from the seashore (around 200-500 m), and the existence of sea lice.

Another factor which also affects socioeconomic status in society is income. According to Soekanto (1992), that income from certain jobs can determine the level of social status. Being on the beach has its advantages for the people in Nemberala Village, one of which being seaweed farmers. Working as a seaweed farmer is currently still the main choice of the community in Nemberala village. Part of the community stated that their economic condition started to improve since seaweed was regarded as a livelihood. This can be seen from their houses if previously they admitted to have a house made of wooden walls and hay/Palmyra leaves roof, now their house have utilized concrete walls and zinc roof.

The average income of seaweed farmers was Rp1,000,000 - Rp3,000,000 per one time harvest. Prior to the oil spill incident of Montana, Australia, the seaweed harvest could be performed every week while today it could only be realized once or twice a month. In addition the existence of sea lice also effects the seaweed growth. If averaged every month, the total income of seaweed farmers in Nemberala Village is IDR 2,000,000 - IDR 6,000,000 per month. This income is very high compared to other jobs in Nemberala Village. Below is a description of community income in Nemberala village:

Table 3 - Community Income List in Nemberala Village in 2019

\begin{tabular}{|c|c|c|}
\hline No & Type of Occupation & Income per month (Rp) \\
\hline 1 & Civil servant & $1,500,000-5,700,000$ \\
\hline 2 & Honorary employee & $250,000-1,000,000$ \\
\hline 3 & Private sector employee & $500,000-1,500,000$ \\
\hline 4 & Weaving craftsmen & $1,000,000-3,000,000$ \\
\hline 5 & Owner of kiosk & $500,000-2,000,000$ \\
\hline
\end{tabular}

Source: Managed by the Author Based on Results of Interviews in 2019.

When compared with working hours and wages obtained, the income of seaweed farmers is much higher than other jobs, because every day it is only needed 14.00-18.00 WITA or when the seawater recedes. As for another job such as civil servants, they have to work starting at 08:00 WITA - 16:00 WITA, as well as other jobs which also take longer than seaweed farmers. This is the reason why seaweed farmers are the most popular work done by the people of Nemberala Village.

Speaking of income, one important aspect to note is regional minimum wages. In 2019, the NTT provincial minimum wage was Rp1,793,298, but the government has not issued the Rote district minimum wage for 2019, but in 2017 amounting to Rp1,525,000 this amount is the same as NTT provincial wages in 2017 , so it can be estimated that wages in Rote Ndao Regency in 2019 it ranged around Rp1,793,298. The income of seaweed farmer is higher two times than the minimum wage of NTT Province and Kupang City.

Based on BPS data, in 2014 the need for decent living in Rote Ndao District was fulfilled at a cost of Rp1,458,922 per month and the minimum wage level of Rote Ndao 
District was around Rp1,010,000 per month. When compared, community income in 2014 was around $30.7 \%$ smaller than the community's decent living needs in Rote Ndao. If we look at the annual inflation rate in Indonesia where every year is around $8.5 \%$ per year, then the size of the community's decent living needs in 2019 by using the baseline needs for decent living in 2014, which is Rp2,193,715.

In addition, according to BPS data in 2008, revenues divided into 4 groups and seaweed farmers are classified as very high-income groups, because their income is around IDR 3,000,000 - IDR 6,000 per month. Seaweed farmer is one of the two works that categorized as the very high-income group category. This can be seen from their houses if previously they admitted to have a house made of wooden walls and hay/Palmyra leaves roof, now their house have utilized concrete walls and zinc roof. Moreover, with the high income, seaweed farmers afford to give proper education to their children and also buy a private vehicle, such as motorcycle and car.

\section{CONCLUSION}

In general, the socio-economic status of seaweed farmer in Nemberala village is in the middle class. In term of education, even though the seaweed farmer only graduates from elementary school, but the existence of seaweed has improved community ability to pay the tuition fee and another cost for education. While, in term of occupational status, seaweed farmer is one of the favorite jobs in Nemberala village and categorized as a very high-income group in the community. The fact that working as a seaweed farmer is not a professional job does not make seaweed farmer struggle to meet family needs, instead, they have the capability to build permanent housing, buy the vehicle, and provide proper education to their children.

\section{REFERENCES}

1. Bradley, R.H. and Corwyn, R.F. 2002. Socioeconomic Status and Child Development. Annual Review of Psychology, 53, 371-399. http://dx.doi.org/10.1146/annurev.psych.53.100901.135233.

2. Creswell, J. W. 2010. Research Design: Pendekatan Kualitatif, Kuantitatif, dan Mixed. Yogjakarta: PT Pustaka Pelajar.

3. Coleman, J.W., \& Cressey, D.R. 1999. Social Problem. New York: Longman.

4. Coleman, J.W., \& Kerbo, H.R. 2002. Social Problem. $8^{\text {th }}$ edition. Upper Saddle River, NJ: Preatice-Hall.

5. Kaare, S. 2009. Diferensiasi Sosial. Bina Aksara. Yogyakarta.

6. Miller, Delbert C., \& Salkind, Neil J. 2002. Handbook of Research Design and Social Measurement. 6th Edition. SAGE Publications, Inc.

7. Neuman, W Lawrence. 2016. Metodologi Penelitian Sosial: Pendekatan Kualitatif dan Kuantitatif. Edisi Ketujuh. Jakarta: PT. Indeks.

8. Nichol, H.W., Brown, S \& Haynes, W. 2011. Social Class and Socioeconomic Status: Relevance and Inclusion in MPA-MPP Programs. Journal of Public Affairs Education. 17:2, 187-208. DOI: 10.1080/15236803.2011.12001638.

9. Sedarmayati. 2001. Sumber Daya Manusia dan Produktivitas Kerja. Bandung: Mandar Maju.

10. Soekanto, S. 1992. Memperkenalkan Sosiologi. Jakarta: Rajawali Press.

11. Soekanto, S. 2001. Sosiologi Keluarga. Jakarta: Rajawali Press.

12. Central Bureau of Statistics (BPS) Republic Indonesia, www.bps.go.id.

13. ISCO-08, International Standard Classification of Occupations: Structure, group definitions and correspondence tables, Volume I. 2012.

14. Presidential Regulation Number 131 of 2015 about Determination of Disadvantaged Regions Year 2015-2019. 